\title{
THE MIGRATION OF ASEAN’S WORKER TO JAPAN
}

\author{
Azhar Harun ${ }^{1}$, Shafee Saad \\ School of Government, College of Law, Government \& International Studies, Universiti Utara Malaysia
}

\section{INTRODUCTION}

The research will analyse the causes and consequences of the recent dramatic increases of migration from Malaysia and selected ASEAN countries (Thailand and Philippine) to Japan. The research aims at learning some general characteristics of the migrations, and linking them to theoretical explanations of migration and its place in the process of globalization. The research main question is; how do Malaysian and selected ASEAN countries migrants enter to work in Japan both legally and illegally?

And what are the possible consequences for the receiving countries, in terms of social, cultural and political change? To answer these questions, The researcher have to do some field research both in Japan as a host country and in Malaysia and selected ASEAN countries (Thailand and Philippine) as a home country.

\section{MIGRATION IN JAPAN}

The number of foreigners entering Japan has been rising sharply. The number of foreign arrivals in 1992 was four million, the number of foreigners registered as living in the country was 1.3 million, and the number of foreigners who overstayed the tourist visas most foreigners use to enter Japan was about 300,000.

There are only about 100,000 legal foreigners among the country's 62 million workers. About one-fourth of these legal foreign workers are entertainers, one-fourth are engaged in international services, including English teaching, and 10 percent are engineers.

Japan does not permit the importation of unskilled foreign workers, but it is believed that 300,000 to 500,000 illegal foreign workers in the country, mostly filling so-called 3-D jobs--dirty,

\footnotetext{
${ }^{1}$ h.azhar@uum.edu.my
} 
dangerous, and difficult. Over 60,000 foreign workers were apprehended in 1992 and 1993, with which two-thirds were from three home countries namely, Malaysia, Iran, and Korea. Each country accounted for about 14,000 apprehensions. About four-fifths of the illegal foreign workers were men, in which half of them were working in construction and one-fourth were working in factories. Mean while, One-third of the women detected were hostesses, and another one-sixth were working in factories.

\section{DATA OF THE FOREIGN POPULATION IN JAPAN}

The number of registered foreigners working in Japan is 1,778,462 as of December 2001, which is $1.4 \%$ of the Japanese population. The number of foreign females is 945,149 (53\%). The number of those with permanent residency status is 684,853 .

Table 1. The numbers of registered foreigners as of December 2001

\begin{tabular}{|c|c|c|c|c|c|c|c|}
\hline & Korea & China & Brazil & Philippines & Peru & US & Total \\
\hline Male & 298,984 & 164,803 & 145,924 & 24,552 & 27,512 & 29,265 & 833,313 \\
\hline Female & 333,421 & 216,422 & 120,038 & 132,115 & 22,540 & 16,979 & 945149 \\
\hline Total & 632,405 & 381,225 & 265,962 & 156,667 & 50,052 & 46,244 & $1,778,462$ \\
\hline $\begin{array}{c}\text { Permanent } \\
\text { Residents }\end{array}$ & 503,610 & 62,838 & 20,291 & 26,994 & 11,064 & 6915 & 684,853 \\
\hline
\end{tabular}

(Source: Japan Immigration Association, Statistics on the Foreigners Registered in Japan 2002)

The number of foreigners who have overstayed their visas is 224,067 as of 1 January 2002.

Table 2. The numbers of overstaying foreigners as of 1 January 2002.

\begin{tabular}{|c|c|c|c|c|c|c|c|}
\hline & Korea & Philippines & $\begin{array}{c}\text { Mainland } \\
\text { China }\end{array}$ & $\underline{\text { Thailand }}$ & Malaysia & Taiwan & \multirow{2}{*}{ Total } \\
\hline Male & 20,747 & 10,456 & 15,749 & 8,020 & 5,280 & 4,346 & 118,122 \\
\hline Female & 34,417 & 19,193 & 11,833 & 8,905 & 4,817 & 4,644 & 105,945 \\
\hline Total & 55,164 & 29,649 & 27,582 & 16,925 & 10,097 & 8,990 & 224,067 \\
\hline
\end{tabular}

(Source: Ministry of Justice, Japan 2002)

\section{OBJECTIVE OF THE STUDY}

The research will analyse the causes and consequences of the recent dramatic increases of migration from Selected ASEAN Countries to Japan. The ASEAN countries are include 10 countries, likes Malaysia, Thailand, Indonesia, Philippine, Singapore, Brunei, Myanmar, Kampuchea, Vietnam and Laos. But, this research will selected some ASEAN countries like, Malaysia, Thailand and Philippine. This is because, from the above data shown many people from Malaysia, Thailand and Philippine enter to work in Japan.

The research aims at learning some general characteristics of the migrations, and linking them to theoretical explanations of migration and its place in the process of globalization. The research main question is; how do the people from Selected ASEAN Countries migrants enter to work in Japan both legally and illegally? And what are the possible consequences for the receiving countries, in terms of social, cultural and political change? To answer these questions, The researcher have to do some field research in Japan as a host country and some selected ASEAN countries as a home country. The specific of the objective study can list belows: 
1. To analyse the effect of the Malaysian income and selected ASEAN countries incomes derived in Japan to the Malaysian economy and selected ASEAN countries economy, especially to the Malaysian and selected ASEAN countries Gross National Product (GNP).

2. To analyse the possible consequences of Malaysian emigrants and selected ASEAN countries emigrants on Japan, in terms of social, cultural and political change.

3. To study the real involvement of Malaysian emigrants and selected ASEAN countries emigrants (both legally and illegally) in the Japan economy.

\section{METHODOLOGY OF THE STUDY}

The research will include some field research both in Japan as a host country and in Malaysia and selected ASEAN countries (Thailand and Philippine) as a home country. The data will base on secondary data and primary data as below:

Secondary Data:

1. Library research on material related to the Malaysian people migration and selected ASEAN countries people to Japan.

2. Data compile by government agency (Malaysia) including Department of Statistics, Department of Immigration and Embassy of Malaysia and selected ASEAN countries in Tokyo.

3. Data also compile from International agency namely, Embassy of Japan, Thailand and Philippine in Kuala Lumpur and Department of Statistics in Bangkok (Thailand), Manila (Philippine) and Tokyo (Japan).

Primary Data:

1. Data from interviewing government agency, Ministry officer, embassy officer from Embassy of Malaysia, Thailand and Philippine in Tokyo and Embassy of Japan, Thailand and Philippine in Kuala Lumpur. Data also will get from interviewing custom officer

2. Data from interviewing Japanese company who have experience in the Malaysian and selected ASEAN country's worker migration.

To obtain the good results, the data from above methodology will be analysed through the regression, crosstabulation and frequency technique by SPSS Program (The System Package For Social Sciences Program). And for facilitate in analysed these data, several models will be formed from the objective studies. These models will be tested through the several hypothesis that will be formed. With this empirical results, it could support strongly to this study. These methodology has choosing because it expected to give the data and the exact result with support the objective study.

\section{LITERATURE REVIEWS}

The literature survey on past and on-going studies on migration of ASEAN countries' people to the East countries like Japan and Korea has been carried out after the Prime Minister of Malaysia introduced 'Look East Policy'. The literature survey can be show are;

The paper from International Symposium at Nihon University (1994) has discuss the problems involved in managing migration during the Pacific century. The paper discuss on the challenge of managing migration to Japan. From the paper, the number of foreigners entering Japan has been rising sharply. The number of foreign arrivals in 1992 was four million, the number of foreigners registered as living in the country was 1.3 million, and the number of foreigners who overstayed the tourist visas most foreigners use to enter Japan was about 300,000. The focus of the papers was on foreigners who 
work in Japan. Japan is well aware of the gap between its policy of no unskilled foreign workers and the reality that at least several hundred thousand such workers are at work. However, there seems to be little consensus for a large-scale immigration solution. If legal immigration to Japan were at British levels of 0.1 percent of the population, Japan would accept about 125,000 immigrants annually. If Japan took as many immigrants as the US, it would accept 500,000 immigrants annually, adding about 0.4 percent to the population annually via immigration. There also seems to be in Japan little enthusiasm for a German-style guestworker system, through which about 10 percent of the workforce in Germany eventually became foreign workers. In the Japanese case, this would imply about six million foreign workers. The selected fear of adopting the German probationary immigrant system-workers who proved to be satisfactory could have their work and residence permits renewed, and send for their families is the settlement of "incompatible foreigners." Japan has not totally rejected the immigration and guestworker options. There are 150,000 mostly Brazilian descendants of turn-of-thecentury Japanese emigrants to South America in Japan, and about 100,000 legal foreign workers. But there is little possibility that these systems will be used to admit more than perhaps 500,000 foreign workers. Instead of opening the front door to legal immigrants, or the guestworker side door, Japan seems most likely to tolerate unauthorized workers and to accept foreign workers through trainee and student sidedoors. If backdoor and non-labor market sidedoors turn out to be the selected avenues through which foreign workers enter Japan, then Japan will be charting a new path to managing migration, implicitly asserting that the unskilled foreign workers present in the country are unwanted or that they are simply acquiring skills to be used at home. It is not clear that the Japanese attempt to use trainee, student, and toleration-of-unauthorized worker policies will prove durable in the 21st century. There are fears that these polices, singly or in combination, could generate immigrant settlement in Japan and socio-economic problems. There was a great deal of discussion of the trainee program. Since 1954, the Japanese government has had a program under which young Asians could enter the country to receive training that would accelerate their country's development. Japanese firms that invested abroad used this program to train future country managers since the 1950s. But over the past five years, small Japanese firms that have never invested abroad have become dependent on foreign trainees. There are 40,000 trainees employed in Japan in 1994. About 90 percent are Asian, including 40 percent from China. Most--83 percent --are employed in manufacturing, usually by small and medium-sized firms. The trainees are generally very well educated by the standards of their countries of origin. Many prominent Japanese advocate expanding the trainee system to permit up to 500,000 foreigners to enter Japan. To most outside observers, this would mean that Japan is opening itself to foreign workers, although calling them trainees. Trainees get paid $\$ 400$ to $\$ 800$ monthly, or just one-fourth to one-half as much as Japanese workers. The quality and content of the training is left up to each firm, so there is room for abuse in both training and in the housing that employers are required to provide trainees. Finally, there is supposed to be a one-year limit on how long trainees can stay in Japan, although employers are pushing for a two-year limit. There was general agreement that the problem of managing immigration--which results from rapid growth and labor shortages--is far preferable to the alternative of emigration pressures. However, there was widespread criticism of the short-term perspective through which most Asian policy makers evaluate migration issues, producing many skeptics of the notion that there will be yet another Asian miracle in finding a mutually beneficial way to manage labor migration and avoid unanticipated results.

Hachiro NISHIOKA, Keiko WAKABAYASHI, Hisashi INABA, Chizuko YAMAMOTO (1991) focused on the migration in Japan in their survey on 'Trends of Migration in Japan'. The sample in this survey include 34,781 persons from the 265 census districts in Japan. They produced Markov transition matrices with one-year/five year transition probabilities The result from this survey, from comparison between stationary distribution of one-year matrix and of five-year matrix, it was shown that from 1985 to 1990 interregional migration patterns in Japan changed toward decentralization of 
population. Since it was observed that on the average 23 per cent of each regional resident are stayer who never moves from birth place, they tried to apply the mover-stayer model to their migration data and calculated ultimate distributions. The trend of decentralization of population was again supported by the mover-stayer model. Up to 1960's,the causes in which people migrated from non-metropolitan to metropolitan areas had been greatest in magnitude. The main reasons for in-migration urban is "occupation", "schooling" and "marriage". Since 1980's, it is interesting to note that the migration within metropolitan areas has been largest in volume. The main reason for in-migration is providing the better residential and natural environment. According to this survey, housing factors account for the largest proportion of moves. This survey has had the first questionnaires about settlement of the households till now. Those questionnaires are about the generation the households belong to and the period they have settled. The generation of the present headships of the households has settled 44.7 per cent of whole respondents. The generation of the parents has settled 16.4 per cent, of the grandparents 10.3 per cent and of the previous grandparents 23.5 per cent. 42.0 per cent of the whole households settled in the time of pre-World War II and 52.0 per cent in post-war. The proportion of households which has settled since 1985 was 16.2 per cent, between 1975 and 198411.5 per cent, between 1960 and 197413.6 per cent, between 1945 and 195911.0 per cent. Investigating on the interregional migration pattern from the view point of the migration history from the birth place to their present residence, they found that the reverse migration who experienced the migration from their birth prefectures to another prefectures occupies about 10\%; (male $10.4 \%$, female $8.5 \%$ ) in contrast with the all cases. Householders and their partners occupied only $14.1 \%$ and $10.8 \%$. It was shown that the scale of reverse migration to their birthplace could not so great influence that can change the pattern of population distribution there basically. They also confirm that Japanese norms of family formation (; for example, the succession of household or relations with their parents) have great regressions or influences on the personal migration experiences.

Manolo I, Abella (1998) from International Labor Organization (ILO) discussed on the Labor Migration to Japan and the East Asian NICs in his article 'Issues in Contemporary Migration in Asia'. From his article, he find, labor shortages in the dynamic growth centers in the region have created another opening for labor migration which is potentially larger than the one that the oil boom created in the Gulf. The growth during the 1980s of migration flows to Japan and the Newly Industrializing Countries (NICs) of East Asia -namely, Hong Kong, Taiwan and Japan - have been impressive and are much larger than what official records reveal. Official records of eight selected Asian countries of emigration show that about 150,000 workers left in 1988 bound for one of these countries compared to only about 30,000 in 1980 . We suspect that if clandestine migration is taken into account the actual numbers could easily be double these reported figures. In Japan alone, labor shortages are widespread in spite of the considerable relocation of labor-intensive industries to neighboring countries through direct foreign investment and in spite of the automation and robotization of many industrial processes. The development of this new migration front has raised a number of new issues and problems. One is the lack of legitimate avenues for the entry of unskilled labor; or where legal entry is possible, very unrealistic quotas have been set on the numbers of those who are permitted to come in. This has led, for example, to a large clandestine flow to Japan where thousands of small enterprises are desperate for workers and where wages are as much as 60 times those in China, 16 times those in the Philippines and eight times those in Malaysia. Japanese authorities estimate that there may be as many as 300,000 foreigners working illegally in the country today. They include many thousands of Chinese workers from the mainland as well as people from Taiwan, Korea, the Philippines, Thailand, Bangladesh, Pakistan and even Iran. In Taiwan, the employment of foreigners also took non-legal avenues until the government decided two years ago to adopt a guest worker immigration policy and to regularize the "illegal." Prior to this move, there were an estimated 40,000 illegal workers in the country (Tsai, 1991). In Hong Kong, more than a million refugees from the mainland entered the 
colony during the period prior to 1980 when a "touch- base" policy was in effect. Net migration was about 400,000 during the 1950s, about 120,000 during the 1960s and another 500,000 during the 1970s. Following revisions of the immigration policy in 1980 and 1982 during which strict controls were established, the flows slowed to a trickle. This was evidently helped by the tremendous growth of Hong Kong investment in labor-intensive industries across the border which are reported to have already created more than two million jobs. Of the total current immigration flows, about 60,000 people are legal immigrants (27,300 consisting mostly of wives and children and about 30,000 as temporary guest workers, including many domestic helpers from the Philippines) and about 27,400 are illegals from the mainland (Arnold, 1989). These probably do not include the thousands of Chinese from the mainland who use Hong Kong as a transit point for clandestine migration to other countries. Of the six countries belonging to the Association of Southeast Asian Nations (ASEAN), three are net importers of labor while the other three are net suppliers. The largest importer of labor, Malaysia, is a fast growing economy that has historically relied on the import of foreign workers to meet shortages of unskilled labor, notably on the plantations. Another net importer, Brunei Darussalam, a tiny state with enormous oil revenues, does not have other industries aside from oil but has a need for foreign workers for infrastructure development and to deliver the services of a wellarticulated welfare state. The last net ASEAN importer, Singapore, a small city-state with only a population of 2.5 million, has relied on foreign labor for construction and shipbuilding and has used the import of domestic helpers as a means to cope with the demands of her female population to participate in formal wage employment. It has, however, adopted measures, such as the foreign workers levy, to discourage its continued reliance on foreign workers and to pressure industries to shift to higher technologies. In Singapore today, however, there are notably more than 200,000 foreign workers, including those who commute daily from the state of Johore in Malaysia. Most of the foreign workers come from neighboring ASEAN countries. Recent estimates put the number of Malaysian workers still in Singapore at between 70,000 to 90,000, including those who commute daily. Indonesians probably comprise another 20,000 workers while Filipinos (mostly female domestic helpers) are estimated at about 50,000. Many Thai workers working without permits were repatriated home in early 1989, but many of them have since returned and now probably number about 16,000 .

The conference report at Scalabrini Migration Centre 'The impact of the Crisis on Migration in Asia' [Graziano Battistella and Maruja Asis (1988)] has focused on the impact of the crisis on receiving countries and sending countries.

The crisis has affected the economies of the receiving countries in varying degrees of severity. Thailand is believed to be hardest hit by the crisis, followed by Korea and Malaysia. Korea's descent, from being the world's 11th largest economy to IMF patient, is perhaps the most dramatic and unexpected. As the crisis unfolded, Hong Kong began to manifest signs of distress early in 1998: rising unemployment, a general slowdown in the economy and the closure of a variety of business establishments. The Japanese economy, which has yet to recover from the collapse of the bubble economy, has not been as adversely affected by the crisis. However, Japan cannot also be expected to help in the economic recovery of the region. Further weakening of the yen and a stagnating economy is expected to slow down demand for imports from and Japanese investments in the region. Singapore, too, has been relatively unscathed in 1997, but because of economic integration in the region, particularly in Southeast Asia, Singapore's economic fate is also very much linked to that of the region. At the other end of the spectrum is Taiwan. Having experienced an economic crisis in 1995 and 1996, Taiwan was, in fact, on its way to economic recovery in 1997. The upturn in the economy in 1997 combined with the following factors - directing more investments in the manufacturing sector rather than in non-productive sectors, installing an inspection program before liberalizing capital accounts, adopting the right sequence towards liberalization and less government intervention in 
pursuing industrial policy - contributed towards steering Taiwan away from the financial crisis. The prospects for recovery in these countries are equally varied. Employment-generating possibilities are particularly daunting in light of slow or negative growth prospects. For 1998, Japan faces the prospect of 1.5 million workers ( 7 percent of its labor force) losing their jobs; an estimated 2 million Thais (5.6 percent of its labor force) are expected to be unemployed; and Japan registered an unemployment rate of 3.9 percent as of March 1998, which translates into 2.7 million unemployed Japanese. Singapore faces good prospects in 1998. Although the appreciation of the Singapore dollar against the other regional currencies will reduce its competitiveness in labor-intensive industries, it will be able to sustain its edge in capital-intensive industries. 1998 also looks bright for Taiwan, mainly because of strong domestic demand. According to economic forecasts, Taiwan could achieve 5.95 percent and 6.39 percent growth rates in 1998 and 1999, respectively. However, Taiwan cannot sustain such growth rates if the crisis persists. How Mainland China fares in reforming its financial institutions and how relationships will be with China will also have a bearing on Taiwan's economic prospects in the long-term.

Indonesia, the Philippines and Bangladesh, by virtue of their direct involvement and/or insertion in the migration system in the region, are among the migration sending countries most affected by the current turmoil. Indonesia, in particular, has emerged as the worst affected nation. From 5 percent in 1997, GDP growth is projected to be negative in 1998 (-5); from 2,500 to the dollar before July 1997, the rupiah adjusted to approximately 11,000 to the dollar these days. The price of primary foods has increased by 50 to 70 percent; inflation has reached approximately 40 percent; and unemployment has risen to perhaps 10 million people. However, the number of people who can now be considered below the poverty line (30 million in urban areas and 70 million in rural areas) is more indicative of the severity of the crisis than unemployment. The rescue package negotiated with IMF brought severe measures to correct imbalances and bring the crisis under management. Although Indonesia initially resisted IMF measures, it eventually gave in, including an increase in the cost of energy. People's reaction to the perceived corruption of the political leadership brought an end to the Suharto regime, which led the country for the past 32 years. However, the coming months will determine whether Habibie will be able to lead Indonesia out of the crisis. Of the five countries most affected by the crisis, the Philippines has been considered in a better position to withstand it. Because of more transparency in the banking system and less inflow of portfolio investments, the Philippine economy was less affected by volatility and the impact of the crisis will be less severe. In fact, the Philippine peso suffered a slightly lower devaluation (40 percent) than the other currencies and it has since stabilized. Nevertheless, the Philippines will go through a severe reduction of growth (GDP is expected to grow only 2.5 percent in 1998), which will translate to increasing unemployment. The consequences of the crisis will also be aggravated by the drought caused by El Nino, with potential social consequences because availability of staple food is threatened. The third sending country, Bangladesh, was practically untouched by the crisis. Considering that only 2 percent of its export is toward the countries of East and Southeast Asia, even later effects will only be minor. However, Bangladesh is already among the least developed countries, with serious challenges and little resources to achieve higher development.

\section{MODEL AND OUTPUT OF THE STUDY}

From the above objective, we can create three group of hypothesis. For easy to understand, these hypothesis will create in the function form. Variables in these hypothesis will separate to independent variables and dependent variables. The empirical method that will be use to test or analyze these hypothesis is Multiple Regression. The three group of hypothesis, can show as below:

1. The hypothesis from the first objective : 


$$
\begin{array}{ll}
\mathrm{GNP}_{\mathrm{M}} & =\mathrm{f}\left(\mathrm{I}_{\mathrm{M}}, \mathrm{I}_{\mathrm{T}}, \mathrm{I}_{\mathrm{P}}\right) \\
\mathrm{GNP}_{\mathrm{T}} & =\mathrm{f}\left(\mathrm{I}_{\mathrm{M}}, \mathrm{I}_{\mathrm{T}}, \mathrm{I}_{\mathrm{P}}\right) \\
\mathrm{GNP}_{\mathrm{P}} & =\mathrm{f}\left(\mathrm{I}_{\mathrm{M}}, \mathrm{I}_{\mathrm{T}}, \mathrm{I}_{\mathrm{P}}\right)
\end{array}
$$

2. The hypothesis from the second objective :

SOCIAL $_{\mathrm{J}}=\mathrm{f}\left(\mathrm{EM}_{\mathrm{M}}, \mathrm{EM}_{\mathrm{T}}, \mathrm{EM}_{\mathrm{P}}\right)$

$\mathrm{CULTURE}_{\mathrm{J}}=\mathrm{f}\left(\mathrm{EM}_{\mathrm{M}}, \mathrm{EM}_{\mathrm{T}}, \mathrm{EM}_{\mathrm{P}}\right)$

POLITIC $_{\mathrm{J}}=\mathrm{f}\left(\mathrm{EM}_{\mathrm{M}}, \mathrm{EM}_{\mathrm{T}}, \mathrm{EM}_{\mathrm{P}}\right)$

3. The hypothesis from the third objective :

$\mathrm{GNP}_{\mathrm{J}} \quad=\mathrm{f}\left(\mathrm{I}_{\mathrm{M}}, \mathrm{I}_{\mathrm{T}}, \mathrm{I}_{\mathrm{P}}\right)$

\section{Definition of Independent Variables}

1. Malaysian People Income $\left(\mathrm{I}_{\mathrm{M}}\right)$

Total Malaysian peoples Income in Japan by year from 1992 - 2002 (both legally and illegally emigrants)

2. Thai People Income $\left(\mathrm{I}_{\mathrm{T}}\right)$

Total Thai people incomes in Japan by year from 1992 - 2002 (both legally and illegally emigrants)

3. Philippine people Income_( $\left.I_{P}\right)$

Total Philippine peoples income in Japan by year from 1992 - 2002 (both legally and illegally emigrants)

4. Malaysian Emigrants $\left(\mathrm{EM}_{\mathrm{M}}\right)$

The number of Malaysian peoples who work in Japan by year from 1992-2002 (both legally and illegally emigrants)

5. Thai Emigrants $\left(\mathrm{EM}_{\mathrm{T}}\right)$

The number of Thai peoples who work in Japan by year from 1992-2002 (both legally and illegally emigrants)

6. Philippine Emigrants $\left(\mathrm{EM}_{\mathrm{P}}\right)$

The number of Philippine peoples who work in Japan by year from 1992-2002 (both legally and illegally emigrants)

\section{Definition of Dependent Variables}

1. Malaysia’s GNP $\left(\mathrm{GNP}_{\mathrm{M}}\right)$

The Malaysia Gross National Product [GNP] by year from $1992-2002$

2. Thailand's GNP $\left(\mathrm{GNP}_{\mathrm{T}}\right)$

The Thailand Gross National Product [GNP] by year from 1992 - 2002

3. Philippine's GNP $\left(\mathrm{GNP}_{\mathrm{P}}\right)$

The Philippine Gross National Product [GNP] by year from 1992 - 2002

4. Japan's GNP $\left(\mathrm{GNP}_{\mathrm{J}}\right)$ The Japan Gross National Product [GNP] by year from $1992-2002$

5. Japan's Social_ $\left(\mathrm{SOCIAL}_{\mathrm{J}}\right)$

The possible consequences to Japan social change, because of Malaysian, Thailand and Philippine emigrants [Qualitative Data]

6. Japan's Cultural (CULTURE J $_{\mathrm{J}}$

The possible consequences to Japan cultural change, because of Malaysian, Thailand and Philippine emigrants [Qualitative Data]

7. Japan Political (POLITIC ${ }_{\mathrm{J}}$ ) 
The possible consequences to Japan political change, because of Malaysian, Thailand and Philippine emigrants [Qualitative Data]

\section{Output of the study:}

1. Equation 1:

$\mathrm{GNP}_{\mathrm{M}}=\mathrm{a}_{0}+\mathrm{a}_{1} \mathrm{I}_{\mathrm{M}}^{* * *}+\mathrm{a}_{2} \mathrm{I}_{\mathrm{T}}+\mathrm{a}_{3} \mathrm{I}_{\mathrm{P}}$

Note $* * * \quad$ Significant at $99 \%$ level

From this equation, the study try to compared between the emigrant's income who working in Japan. In this case, only three countries (Malaysia, Thailand and Philippine) has selected. The hypothesis of this study expected the Malaysian emigrant's income $\left(\mathrm{I}_{\mathrm{M}}\right)$ will be influence The Malaysia's Gross National Product [GNP $\mathrm{GN}_{\mathrm{M}}$.

The output of the study shown the Malaysian emigrant's income $\left(\mathrm{I}_{\mathrm{M}}\right)$ has influence The Malaysia's Gross National Product $\left[\mathrm{GNP}_{\mathrm{M}}\right]$ in positive way. This mean that, if the Malaysian emigrant's income $\left(\mathrm{I}_{\mathrm{M}}\right)$ has increase, The Malaysia's Gross National Product $\left(\mathrm{GNP}_{\mathrm{M}}\right)$ also will increase.

2. Equation 2:

$\mathrm{GNP}_{\mathrm{T}}=\mathrm{b}_{0}+\mathrm{b}_{1} \mathrm{I}_{\mathrm{M}}+\mathrm{b}_{2} \mathrm{I}_{\mathrm{T}}^{* * *}+\mathrm{b}_{3} \mathrm{I}_{\mathrm{P}}$

Note $* * * \quad$ Significant at $99 \%$ level

From this equation, the study also try to compared between the emigrant's income who working in Japan. The hypothesis of this equation expected the Thai emigrant's income $\left(\mathrm{I}_{T}\right)$ will be influence The Thailand's Gross National Product [GNP $\mathrm{GN}_{\mathrm{T}}$.

The output of the study shown the Thai emigrant's income $\left(\mathrm{I}_{\mathrm{T}}\right)$ has influence The Thailand's Gross National Product $\left[\mathrm{GNP}_{\mathrm{T}}\right]$ in positive way. This mean that, if the Thai emigrant's income $\left(\mathrm{I}_{\mathrm{T}}\right)$ has increase, The Thailand's Gross National Product $\left(\mathrm{GNP}_{\mathrm{T}}\right)$ also will increase.

3. Equation 3:

$\mathrm{GNP}_{\mathrm{P}}=\mathrm{C}_{0}+\mathrm{C}_{1} \mathrm{I}_{\mathrm{M}}+\mathrm{C}_{2} \mathrm{I}_{\mathrm{T}}+\mathrm{C}_{3} \mathrm{I}_{\mathrm{P}}^{* * *}$

Note $* * * \quad$ Significant at $99 \%$ level

From this equation, the study also try to compared between the emigrant's income who working in Japan. The hypothesis of this equation expected the Philippine emigrant's income $\left(\mathrm{I}_{\mathrm{P}}\right)$ will be influence The Philippine's Gross National Product [GNP $\mathrm{P}_{\mathrm{P}}$.

The output of the study shown the Philippine emigrant's income $\left(I_{P}\right)$ has influence The Philippine's Gross National Product $\left[\mathrm{GNP}_{\mathrm{P}}\right]$ in positive way. This mean that, if the Philippine emigrant's income $\left(I_{P}\right)$ has increase, The Philippine's Gross National Product $\left(G P_{P}\right)$ also will increase.

4. Equation 4:

SOCIAL $_{\mathrm{J}}=\mathrm{d}_{0}+\mathrm{d}_{1} \mathrm{EM}_{\mathrm{M}}+\mathrm{d}_{2} \mathrm{EM}_{\mathrm{T}}+\mathrm{d}_{3} \mathrm{EM}_{\mathrm{P}}^{* * *}$

Note $* * * \quad$ Significant at $99 \%$ level

This equation try to analyses the affect of the select ASEAN countries emigrants to the Japan social life. The number of each country's emigrants may be effect the Japan's social life in aspect of social problem like drugs, gangsterism or robbery. This hypothesis expected that the largest number of ASEAN country's emigrants like Philippine $\left(\mathrm{EM}_{\mathrm{P}}\right)$, will be affected more problem to the Japan social than the smaller number of ASEAN country's emigrants (Thailand and Malaysia). And, between Thailand and Malaysia, the number of Thai emigrants are larger than Malaysian emigrants, so this hypothesis expected that Thai emigrants may be make more problem than Malaysian emigrants.

The output of the study shows that the Philippine emigrants are the major factor influencing the Japan social life. It is followed by Thai and Malaysian emigrants. This output has 
supported the early hypothesis that the number of the country's emigrants affect the Japan social life in many aspects like drugs, gangsterism or robbery. Because the Philippine emigrant number is the largest, this factor $\left(\mathrm{EM}_{\mathrm{P}}\right)$ is the major determinant in influencing the Japan social life (SOCIAL S .

5. Equation 5:

CULTURE $_{\mathrm{J}}=\mathrm{e}_{0}+\mathrm{e}_{1} \mathrm{EM}_{\mathrm{M}}+\mathrm{e}_{2} \mathrm{EM}_{\mathrm{T}}+\mathrm{e}_{3} \mathrm{EM}_{\mathrm{P}}$

This equation tries to analyses the affect of the selected ASEAN country's emigrants to the Japan culture (CULTURE $E_{K}$ ). The number of each country's emigrants also may be affected the Japan's culture in aspect of culture problem. The output of the study did not supported the early hypothesis. It shows that all factors do not influencing Japan culture. This is because, the Japan people has an unique culture that cannot be influencing by the culture from another countries.

6. Equation 6:

POLITIC $_{\mathrm{J}}=\mathrm{f}_{0}+\mathrm{f}_{1} \mathrm{EM}_{\mathrm{M}}+\mathrm{f}_{2} \mathrm{EM}_{\mathrm{T}}+\mathrm{f}_{3} \mathrm{EM}_{\mathrm{P}}$

This equation tries to analyses the affect of the selected ASEAN country's emigrants to the Japan politic (POLITIC $)_{\mathrm{J}}$ ). The number of each country's emigrants also may be affected the Japan's politic in aspect of worker association rule or election problem. The output shows, all factors (independent variables) do not significant with the dependent variable (POLITIC J $_{\text {). }}$. This mean that the output of the study did not supported the early hypothesis. It shows that all factors like $\mathrm{EM}_{\mathrm{M}}, \mathrm{EM}_{\mathrm{T}}$ and $\mathrm{EM}_{\mathrm{M}}$ do not influencing Japan politic (POLITIC $\mathrm{J}_{\mathrm{J}}$. This is because, the Japan political change or any movement in politic will be control by Japan peoples themselves.

7. Equation 7:

$\mathrm{GNP}_{\mathrm{J}}=-3390.997-1.126 \mathrm{I}_{\mathrm{M}}+2.172 \mathrm{I}_{\mathrm{T}}+10.873 \mathrm{I}_{\mathrm{P}}$

$(-0.677) \quad(3.644) \quad(1.705)$

$\mathrm{F}-$ Test $=136.676^{*} \quad(*$ Significant at $90 \%$ level $)$

$\mathrm{R}$ - Square $=0.998$

This equation tries to analyses the affect of the emigrants income who working in Japan to Japan Economy $\left(\mathrm{GNP}_{\mathrm{J}}\right)$. The independent variables from selected ASEAN countries like Income from Malaysian worker who work in Japan $\left(\mathrm{I}_{\mathrm{M}}\right)$, Income from Thai worker who work in Japan $\left(\mathrm{I}_{\mathrm{T}}\right)$ and Income from Philippine worker who work in Japan $\left(\mathrm{I}_{\mathrm{P}}\right)$ are expect to influencing the dependent variable, Japan Economy $\left(\mathrm{GNP}_{\mathrm{J}}\right)$. The output shows, all factors (independent variables) do not significant with the dependent variable $\left(\mathrm{GNP}_{\mathrm{J}}\right)$, although the Ftest is significant and R-Square is very high. This mean that the output of the study did not supported the early hypothesis. It shows that all factors like $\mathrm{I}_{\mathrm{M}}, \mathrm{I}_{\mathrm{T}}$ and $\mathrm{I}_{\mathrm{M}}$ do not influencing Japan Economy $\left(\mathrm{GNP}_{\mathrm{J}}\right)$. This output also mean that the Japan Economy $\left(\mathrm{GNP}_{\mathrm{J}}\right)$ did not depended to the foreign worker but it depended to the Japan workers themselves.

\section{PROBLEMS AND DIFFICULTIES}

The time series data collection is noted as one of the major problem in this study. We cannot find the data more than ten years. The institution namely, Ambassador of Japan, Thailand and Philippine in Malaysia tried to keep the data as secreted. The data from many university's library in Malaysia is very limited.

\section{CONCLUSION AND ECOMMENDATIONS}

This paper has utilized selected ASEAN countries and Japan's economy time series data for the period 1994 - 2000 to ascertain the influence of a number of variables that are commonly cited by 
previous researchers as important determinants of the migration growth from selected ASEAN countries to Japan. The model of the first part estimated here uses the Selected ASEAN economy as the dependent variable and the income of Thai worker $\left(\mathrm{I}_{\mathrm{T}}\right)$, Philippine worker $\left(\mathrm{I}_{\mathrm{P}}\right)$ and Malay worker $\left(\mathrm{I}_{\mathrm{M}}\right)$ who works in Japan as independent variables.

In general, the study found that increases in income of Thai people who work in Japan enhance Thailand Economy. An increase in income of Malay worker who work in Japan also enhance Malaysia Economy. And, increases in income of Philippine worker who work in Japan also enhance Philippine Economy. The implication could be drawn from this study; the extent of each economy of selected ASEAN countries is largely influenced by income of their worker who works in Japan. For supported the economy growth of ASEAN countries, The Japan government should consider relaxing some of the restrictions to foreign worker (especially to ASEAN worker) who work in Japan.

The models of the second part used social, culture, politic in Japan as the dependent variable and total of migration worker from selected ASEAN countries as independent variables. In this part, the study found that increase in total of emigrant from Philippine will influence social problem, like drugs, gangsterism or robbery. This is because, the totals of Philippine emigrant are the largest, if comparing to the Thai and Malay emigrant. For peace, The Japan government should consider or more control to the Philippine emigrant.

\section{BIBLIOGRAPHY}

Source of Secondary Data

Asia weekly Magazine From 1992 - 2002

Graziano Battistella and Maruja Asis, 'The impact of the Crisis on Migration in Asia'(1988)

Hachiro NISHIOKA, Keiko WAKABAYASHI, Hisashi INABA, Chizuko

YAMAMOTO, ‘Trends of Migration in Japan', Tokyo, Japan (1991)

Japan Immigration Association, Statistics on the Foreigners Registered in Japan 2002, Tokyo, Japan (2002)

Ministry of Justice, Tokyo, Japan (2002)

Manolo I, Abella, 'Issues in Contemporary Migration in Asia’, International Labor Organization (ILO) (1998)

Organization for Economic cooperation and Development (2000) “Trend in international migration", Paris OECD Publication Report From Ministry of Labor, Malaysia (2004)

Report From Ministry of Labor, Malaysia (2004)

Report from International Symposium at Nihon University (1994)

Report From Embassy of Japan, Kuala Lumpur, Malaysia (2004).

Source of Primary Data

The information base from the interviewing some officer of the Japan Embassy in Malaysia

The last model used the Japanese economy as the dependent variable and the income of Thai worker $\left(\mathrm{I}_{\mathrm{T}}\right)$, Philippine worker $\left(\mathrm{I}_{\mathrm{P}}\right)$ and Malay worker $\left(\mathrm{I}_{\mathrm{M}}\right)$ who works in Japan as independent variables. This study founds, the independent variables did not influence the dependent variable $\left(\mathrm{GNP}_{\mathrm{J}}\right)$. This mean that the factors like, income from selected ASEAN worker who work in Japan $\left(\mathrm{I}_{\mathrm{M}}, \mathrm{I}_{\mathrm{T}}\right.$ and $\left.\mathrm{I}_{\mathrm{M}}\right)$ do not influencing Japanese Economy $\left(\mathrm{GNP}_{\mathrm{J}}\right)$. This founds also mean that the Japanese Economy $\left(\mathrm{GNP}_{\mathrm{J}}\right)$ did not depended to the foreign worker but it really depended to the Japanese workers themselves.

(These output from this progress report based on secondary data and less than ten years only. The final report will base on primary and secondary data and the data more than ten years will be collect) 